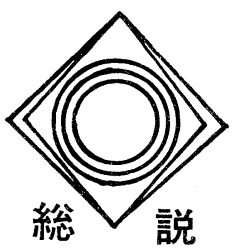

1. はじめに

米国の石炭直接液化の技術開発は, 多くのプロセス が発想とシステムの優劣を競う時代から，ごく少数の 選ばれたプロセスの大規模試験プラント（パイロット およびデモンストレーションプラント）の完遂を競う 時代に入っている, その間にも,プロセスの改善は進行 しており，瀝青炭を用いてボイラ一用燃料を生産する プロセス技術の一応の確立のあと, 炭種の拡大と, 上 り軽質化乙て輸送用燃料油, 中, 軽質燃料油とする方 式が研究されている。本稿では主として以上の状況を 述べることをする1)。な技，米国の石岸事情につい ても概略説明し, 石炭からの合成燃料に対する政策と 合わせて，液化技術開発の動向を探るための一助にし たい。

\section{2. 米国の石炭資源と石炭政策}

2.1 炭種別埋蔵量と生産見通乙

米国の石炭については連邦政府の諸機関で系統的か つ包括的な調查を行っている。図 1 抢よび表 1 亿炭種 別石炭賦存状況之埋蔵量を示す。米国は世界の石炭可

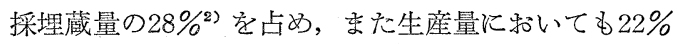
3)を占めている。

米国内の石炭理藏量の $1 / 4$ はケンタッキー州, ウエ ストバージニア州, ヴァージニア州, ペンシルヴァニ ア州, オハイオ州を中心としたアパラチア地区にあ り，1/4 は中央部, 残り $1 / 2$ は西部地区 (西経 100 度 以西）飞賦存している。地区別飞久た品質上の特性と しては図 2 に示すように, アパラチア地区の石炭はカ ロリーが高く $(12,000 \sim 14,000 \mathrm{BTU} / \mathrm{lb})$ 平均硫黄分 も高い。一方, 西部地区のものは低カロリ一の业瀝青 岸や炭化度が低くて水分の多い褐炭が多い。また，西 部炭は東部炭に比べ硫黄分が低く, 連邦政府の品質基 準 (当該燃料の発熱量 100 万 BTU 当りの燃料中に 含まれる硫黄分の量) 飞合格する炭量が多い。東部炭 は東部海岸地区に大消費地を控えてはいるが，硫黄分 が多く公害対策上好すしくなく, 精製炭や液化, ガス

*研究開発室 **新燃料部

東京都千代田区丸の内3-1-1
化などとよるクリーンエネルギー化が試 みられてい $ろ^{7)}$ 。

また，西部炭のもらひとつの特徵として，採掘方法 があげられる。全米の総生産量は1979年で 7 億 7,000 万 $\mathrm{t} /$ 年 である。その採掘方法は, 一般地下坑掘り (Underground mining) と地表掘り (Surface mining) 飞分けられる。現状法打る全米の石炭生産は地表掘 り $62 \%$ ，地下抗掘り $38 \%$ で㘯る。表 2 亿示すように将 来の石炭生産量の見通しは和もに西部炭の地表掘りに よる生産の増加が見込まれている。

西部の一般炭開発上の問題点としては西部諸州にお ける石岸賦存地の大部分が連邦所有地, 州有地, イン ディアン留保地であり, 西部炭埋蔵量の約 $85 \%$ が公的 管理下に放る。従って, 公有地リ一ス権取得は連邦リ 一ス政策の動向や石炭の生産増加と利用拡大に関する 連邦エネルギー政策の動向によって大きく影響され $3^{\text {9)。 }}$

\section{2 米国の石炭政策}

米国政府の石炭政策は特もに (1)鉱山開発に関する もの (2)発電用石炭の拡大に関するもの (3)石炭の転 換利用による代替エネルギー"生産に関するるのであ る。

(1)については他紙面を参照されたい92。(2)発電用石 炭の利用拡大政策は1974年ニクソン大統領によって The Energy Supply and Environmental Coordination Act (エネルギー供給, 環境調整法) が施行さ れて以来, 発電用燃料は石油・天然ガスから石炭直 焚き，原子力の拡大の方向へ歩灭出した。气の後，フ オード大統領の時, The Energy Policy and Conservation Act (エネルギー政策・節約法一1975年),

カーター前大統領のときは The National Energy Act（国家エネルギー法一1978年）が制定された。乙 かし，現実は1975年から1979年まで，米国のエネルギ 一消費量の中で石炭は18\%から19\%に伸びたに過ざな かった。因みに，部門別石炭消費量と輸出量推移を表 3 亿示す。今後は石㟶焚き発電プラントーの助成策に より石炭の利用拡大を図ろらとしている。 


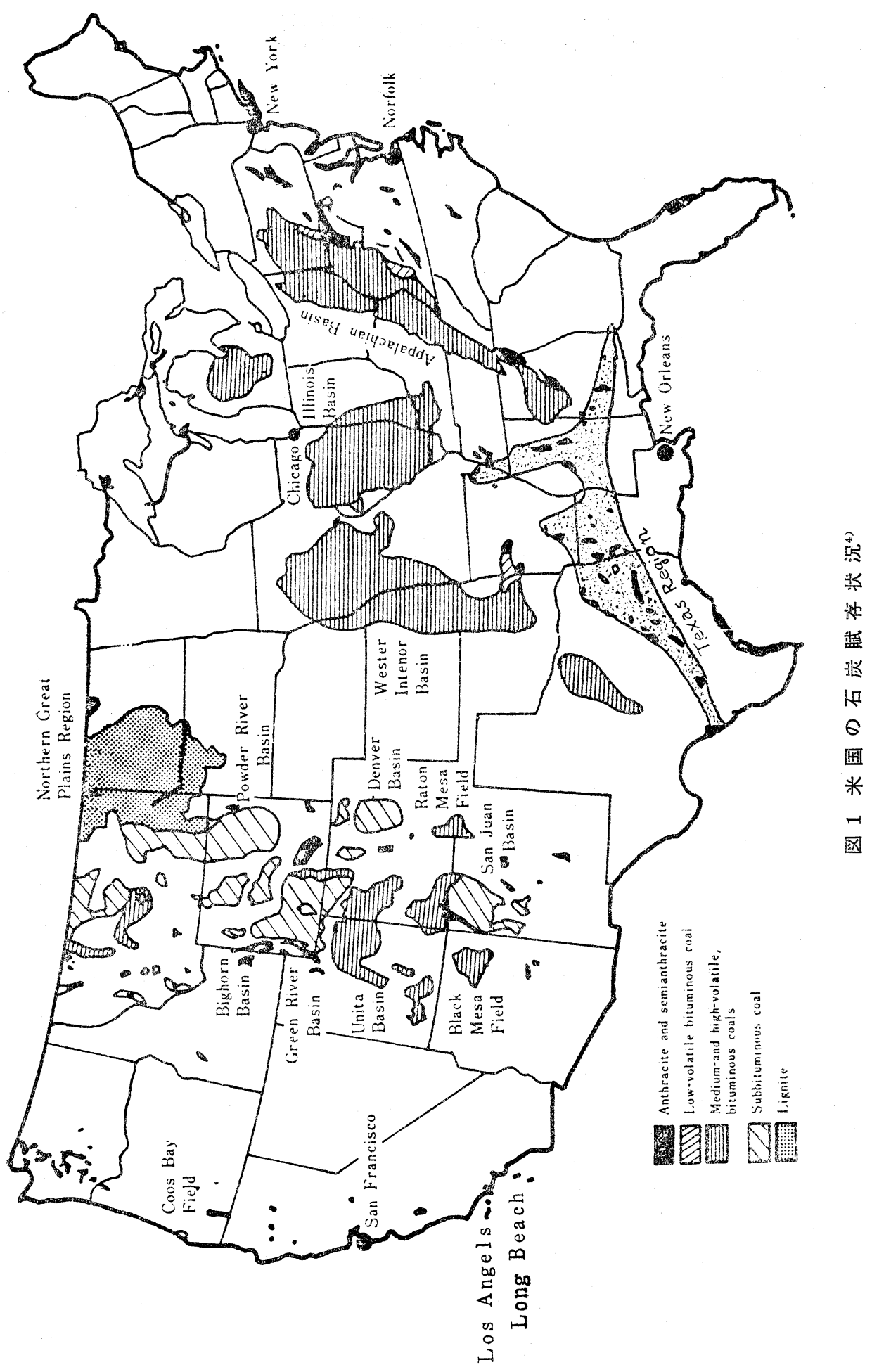


表 1 Estimated remaining coal resources of the united states ${ }^{3)}$

Overburden $0-3,000$ feet

millions $\left(10^{6}\right)$ short tons.

Remaining identified resources, Jan. 1, 1974

\begin{tabular}{rrrrr}
\hline Bituminous & $\begin{array}{c}\text { Sub- } \\
\text { bituminous } \\
\text { coal }\end{array}$ & Lignite & $\begin{array}{c}\text { Anthracite } \\
\text { and } \\
\text { semi- } \\
\text { anthracite }\end{array}$ & Total \\
\hline 13,262 & 0 & 2,000 & 0 & 15,262 \\
19,413 & 110,666 & $(2)^{*}$ & $(3)^{*}$ & 130,079 \\
21,234 & $(4)^{*}$ & 0 & 0 & 21,234 \\
1,638 & 0 & 350 & 428 & 2,416 \\
109,117 & 19,733 & 20 & 78 & 128,948 \\
24 & 0 & 0 & 0 & 24 \\
146,001 & 0 & 0 & 0 & 146,001 \\
32,868 & 0 & 0 & 0 & 32,868 \\
6,505 & 0 & 0 & 0 & 6,505 \\
18,668 & 0 & $(6)^{*}$ & 0 & 18,668
\end{tabular}

Kentucky:

Alabama …..........

Alaska

Arizona

Arkansas

Colorado

Georgia

Illinois

Indiana

Iowa

28,226

0

\section{0}

Western...........

36,120

0

Maryland

1,152

Michigan 205

Missouri

31,184

Montana

2,299

10, 748

New Mexico...........

110

North Dakota

0

Ohio

41, 166

Oklahoma

7,117

Oregon

Pennsylvania............

South Dakota ........

Tennessee ..............

Texas

Utah

Virginia ................

Washington..........

West Virginia .........

Wyoming

Other States

Total

63,940

0

2, 530

6, 048

23, 186

9, 216

1,867

100, 150

12, 703

610

747,357

176, 819

50, 639

\section{0}

0

0

0

284

0

0

0

0

173

0

4, 180

0

123,240

32

485, 766
112,521

350,602

0

$(6)^{*}$

0

0

2,185

0

10, 293

0

0

117

0

(2)*

46

478, 134
28, 226

36,120

1, 152

205

31,184

291, 639

61,391

110

350,602

41, 166

7,117

334

82,752

2,185

2,530

16,341

23, 359

9,551

6,169

100,150

135,943

688 


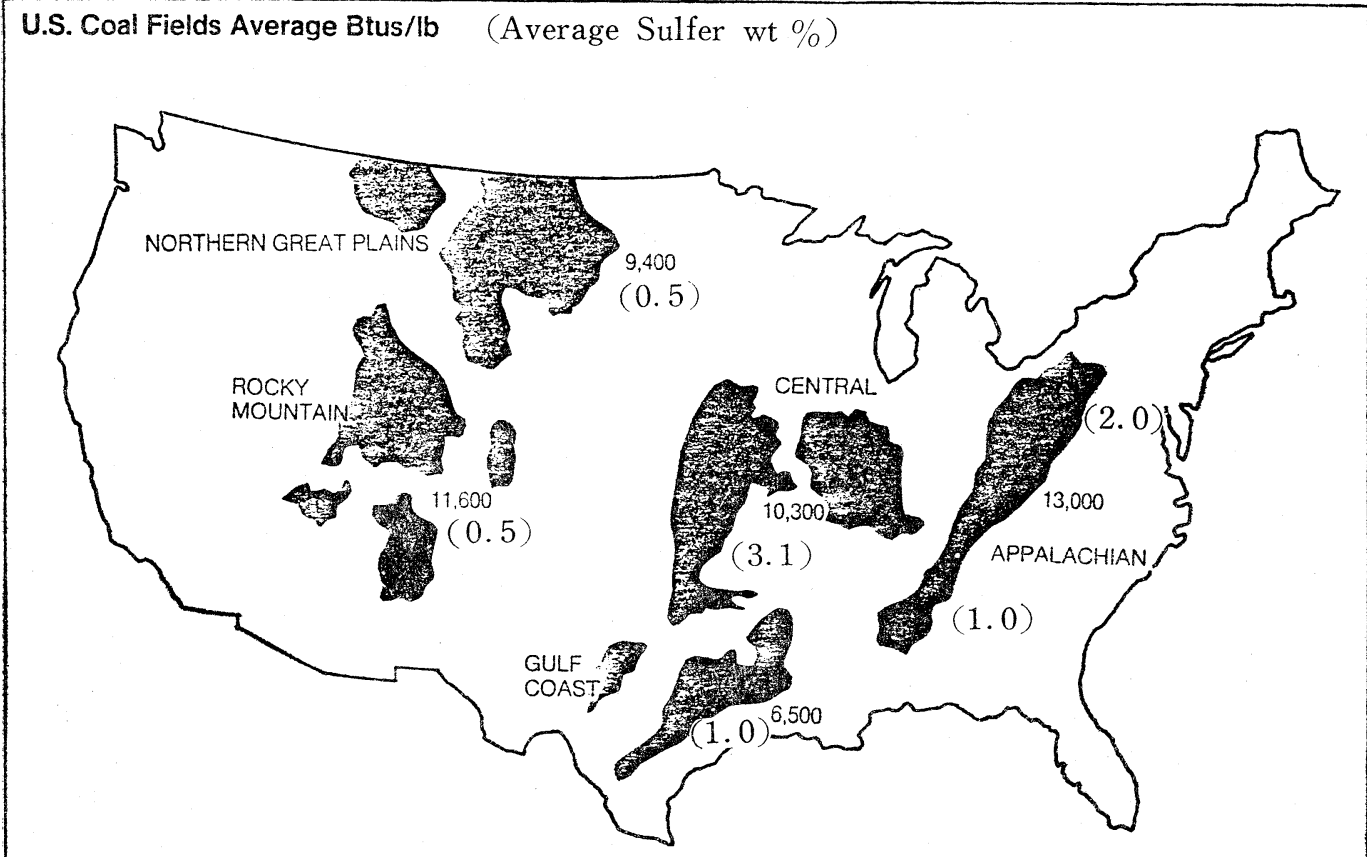

図 2 米国炭の平均発熱量亡平均硫黄分 ${ }^{5) 6)}$

表 2 石炭生産量の見通 L8)

1977-2000 (Million Short Tons)

\begin{tabular}{|c|c|c|c|c|c|c|c|}
\hline \multirow[b]{2}{*}{ Region } & \multirow[b]{2}{*}{1979} & \multicolumn{2}{|c|}{1985} & \multicolumn{2}{|c|}{1990} & \multicolumn{2}{|c|}{2000} \\
\hline & & $\begin{array}{l}\text { Low } \\
\text { Coal } \\
\text { Case }\end{array}$ & $\begin{array}{c}\text { High } \\
\text { Coal } \\
\text { Case }\end{array}$ & $\begin{array}{l}\text { Low } \\
\text { Coal } \\
\text { Case }\end{array}$ & $\begin{array}{c}\text { High } \\
\text { Coal } \\
\text { Case }\end{array}$ & $\begin{array}{l}\text { Low } \\
\text { Coal } \\
\text { Case }\end{array}$ & $\begin{array}{c}\text { High } \\
\text { Coal } \\
\text { Case }\end{array}$ \\
\hline \multicolumn{8}{|l|}{ Appalachia } \\
\hline Underground & 225 & 225 & 240 & 240 & 320 & 375 & 550 \\
\hline Surface & 202 & 130 & 150 & 130 & 160 & 130 & 175 \\
\hline Total & 427 & 355 & 390 & 370 & 480 & 505 & 725 \\
\hline \multicolumn{8}{|l|}{ Midwest* } \\
\hline Underground & 51 & 60 & 80 & 70 & 125 & 120 & 215 \\
\hline Surface & 93 & 75 & 90 & 80 & 105 & 95 & 135 \\
\hline Total & 144 & 135 & 170 & 150 & 230 & 215 & 350 \\
\hline $\begin{array}{l}\text { Gulf Surface } \\
\text { Lignite }\end{array}$ & 25 & 45 & 55 & 55 & 70 & 80 & 100 \\
\hline \multicolumn{8}{|l|}{ West } \\
\hline Uuderground & 16 & 40 & 50 & 50 & 70 & 80 & 100 \\
\hline Surface & 158 & 345 & 360 & 400 & 550 & 620 & 1,225 \\
\hline Total & 174 & 385 & 410 & 450 & 620 & 700 & 1,325 \\
\hline $\begin{array}{l}\text { Total } \\
\text { Production }\end{array}$ & 770 & 920 & 1,025 & 1,025 & 1,400 & 1,500 & 2,500 \\
\hline
\end{tabular}

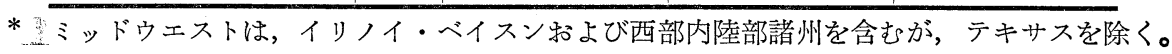


表 3 部門別石炭消費量 ${ }^{10)}$ 之輸出量 ${ }^{3)}$ 推移

(単位: $10^{3} \mathrm{st}(\%)$ )

\begin{tabular}{|c|c|c|c|c|c|c|}
\hline & 力 & コークス用 & 産業・その他 & 民生・商業 & 計 & 輸 \\
\hline 1973 & $\begin{array}{r}389,212 \\
(69.2)\end{array}$ & $\begin{array}{l}94,101 \\
(16.7)\end{array}$ & $\begin{array}{c}68,154 \\
(12.1)\end{array}$ & $\begin{array}{r}11,117 \\
(2.0)\end{array}$ & $\begin{array}{r}562,584 \\
\quad(100)\end{array}$ & 52,903 \\
\hline 1974 & $\begin{array}{r}391,811 \\
(70.2)\end{array}$ & $\begin{array}{l}90,191 \\
(16.2)\end{array}$ & $\begin{array}{l}64,983 \\
(11.6)\end{array}$ & $\begin{array}{l}11,417 \\
(2.0)\end{array}$ & $\begin{array}{r}558,402 \\
(100)\end{array}$ & 59,926 \\
\hline 1975 & $\begin{array}{c}405,962 \\
(72.2)\end{array}$ & $\begin{array}{l}83,598 \\
(14.9)\end{array}$ & $\begin{array}{l}63,670 \\
(11.3)\end{array}$ & $\begin{array}{c}9,410 \\
(1.7)\end{array}$ & $\begin{array}{r}562,641 \\
(100)\end{array}$ & 65,669 \\
\hline 1976 & $\begin{array}{r}448,371 \\
(74.3)\end{array}$ & $\begin{array}{l}84,704 \\
(14.0)\end{array}$ & $\begin{array}{l}61,800 \\
(10.2)\end{array}$ & $\begin{array}{c}8,916 \\
(1.5)\end{array}$ & $\begin{array}{r}603,791 \\
(100)\end{array}$ & 59,406 \\
\hline 1977 & $\begin{array}{r}477,126 \\
(76.3)\end{array}$ & $\begin{array}{l}77,739 \\
(12.4)\end{array}$ & $\begin{array}{c}61,472 \\
(9.8)\end{array}$ & $\begin{array}{c}8,954 \\
(1.4)\end{array}$ & $\begin{array}{r}625,290 \\
(100)\end{array}$ & 53,687 \\
\hline 1978 & $\begin{array}{r}481,235 \\
(77.0)\end{array}$ & $\begin{array}{l}71,394 \\
(11.4)\end{array}$ & $\begin{array}{l}63,085 \\
(10.1)\end{array}$ & $\begin{array}{c}9,511 \\
(1.5)\end{array}$ & $\begin{array}{r}625,225 \\
(100)\end{array}$ & 39,825 \\
\hline 1979 & $\begin{array}{r}528,803 \\
(77.7)\end{array}$ & $\begin{array}{l}77,070 \\
(11.3)\end{array}$ & $\begin{array}{c}65,972 \\
(9.7)\end{array}$ & $\begin{array}{c}9,108 \\
(1.3)\end{array}$ & $\begin{array}{r}680,908 \\
(100)\end{array}$ & 64,783 \\
\hline
\end{tabular}

(3)の石炭の転換利用，つまり石炭から合成天然ガス や液体炭化水素の製造は前述の National Energy Act による石油輸入削減の一手段として考兄られている。 さらに合成燃料開発のるらひとつの目的としては, 環 境対策上の目標を達成させるための技術開発を行うこ とでめる。1980年 6 月, Energy Security Act（エネ ルギー安定確保法）により合成燃料公社を設立し，合 成燃料開発の奨励策を行拈うとした。

Synthetic Fuel Corporation Act（合成燃料公社 法）によれば，合成燃料生産のプログラムとして1987 年 50 万 $\mathrm{B} / \mathrm{D}, 1992$ 年 200 万 $\mathrm{B} / \mathrm{D}$ の生産達成のために 総額 880 億ドル，当初は 200 億ドルの資金支出を行う (表 4)。開発を助長するための税額控除 や融資, 助

\begin{tabular}{|c|c|c|}
\hline & 1987 & 1992 \\
\hline & $\begin{array}{l}\text { Equivalent } \\
\text { oil production } \\
\text { thousand } b / d\end{array}$ & $\begin{array}{c}\text { Equivalent } \\
\text { oil production } \\
\text { thousand } \mathrm{b} / \mathrm{d}\end{array}$ \\
\hline Direct Coal Liquids & 50 & 300 \\
\hline ndirect Coal Liquids & 100 & 400 \\
\hline SNG from Coal & 30 & 150 \\
\hline Medium BTU Gas & 50 & 200 \\
\hline Shale Oil & 230 & 800 \\
\hline \multirow[t]{2}{*}{ Dther } & 40 & 150 \\
\hline & 500 & 2,000 \\
\hline
\end{tabular}

成，共同開発など各種の奨励策を行う計画である。合 成然料開発助成の対象項目は，石炭からの合成燃料 (固体，液体，ガス)，シェールからのガスと液体然 料, タールサンドからの液体燃料, 石油系重質油の軽 質化, 直接燃焼のための石炭, 石油混合燃料 (COM), MHD 発電システム, 水からの水素製造などである。

今年 1 月に就任したレーガン大統領は，合成然料開 発に和ける政府 (DOE) の介入，援助について見直 しを行っている。

\section{3 日本への一般炭輸入の問題点}

米国の1979年の石炭輸出量は約 6,500 万トンで，活 とんぞが治金用歴青炭である。

物子な輸出先は，カナダ $(1,650$ 万トン） 欧州 $(2,0$ 00万トン) 叔よび日本 $\left(1,880\right.$ 万トン) でめる ${ }^{3)}$ 。一 般炭については，すで酒部地区のユタ，コロラド両 州から一部出荷が始まっているが，量的な拡大につい てはさまざるな制約条件が生じている。午の扮もな問 題点は次のような項目であるが，実際の企業化計画に 当っては，具体的に案件ごと解決をしていかねばな らない。

・品質（低カロリー，水分が多い）と用途

・開発の形態（鉱区のリース，インフラ整備）

・港焪の整備, 払張, 改造, 新設

- 内陸輸送と環境問題

\section{3. 石炭液化技術の開発}

3.1 DOE の開発プロジェクトの現況

米国の石炭液化に関する研究開発プロジェクトは 27 


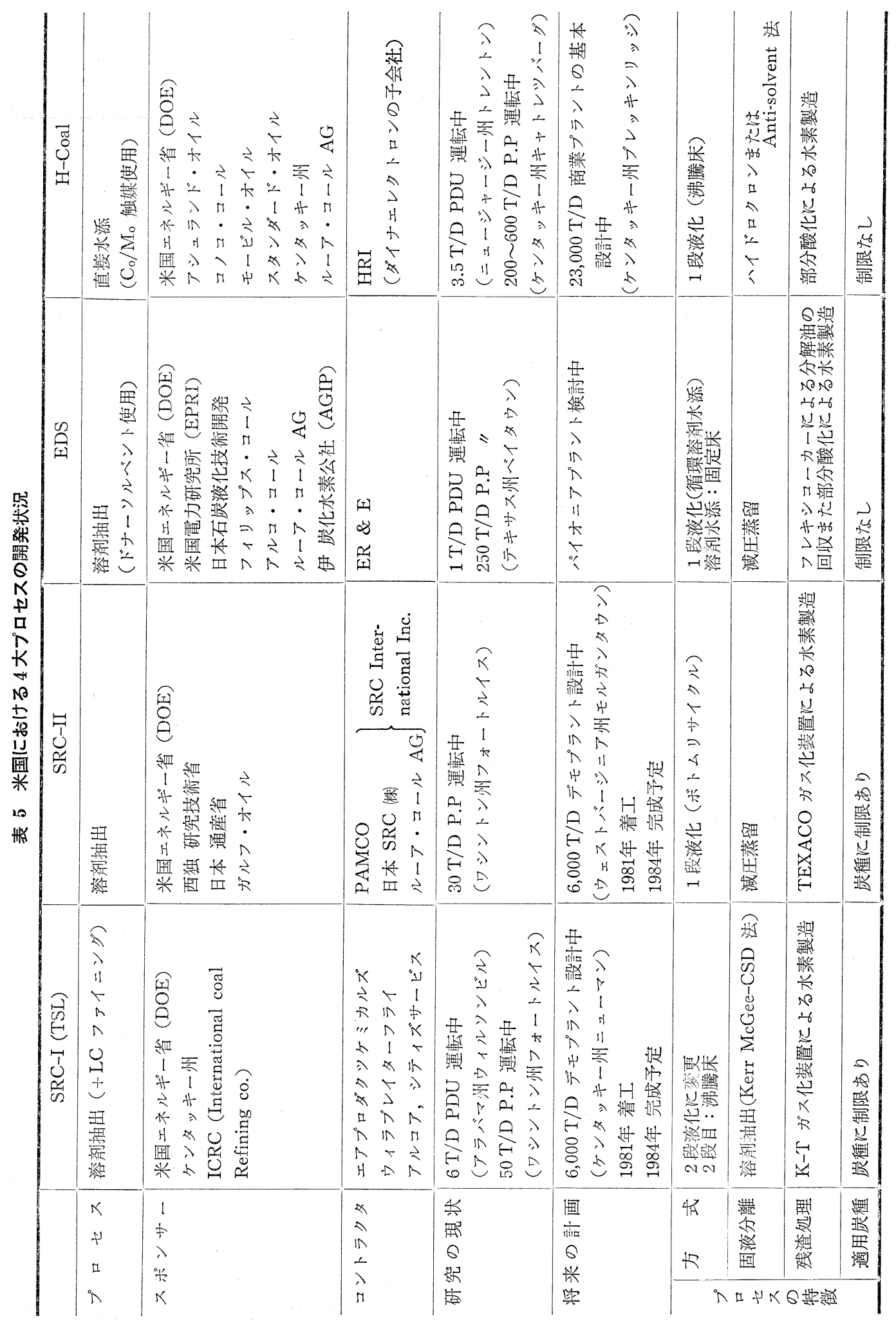




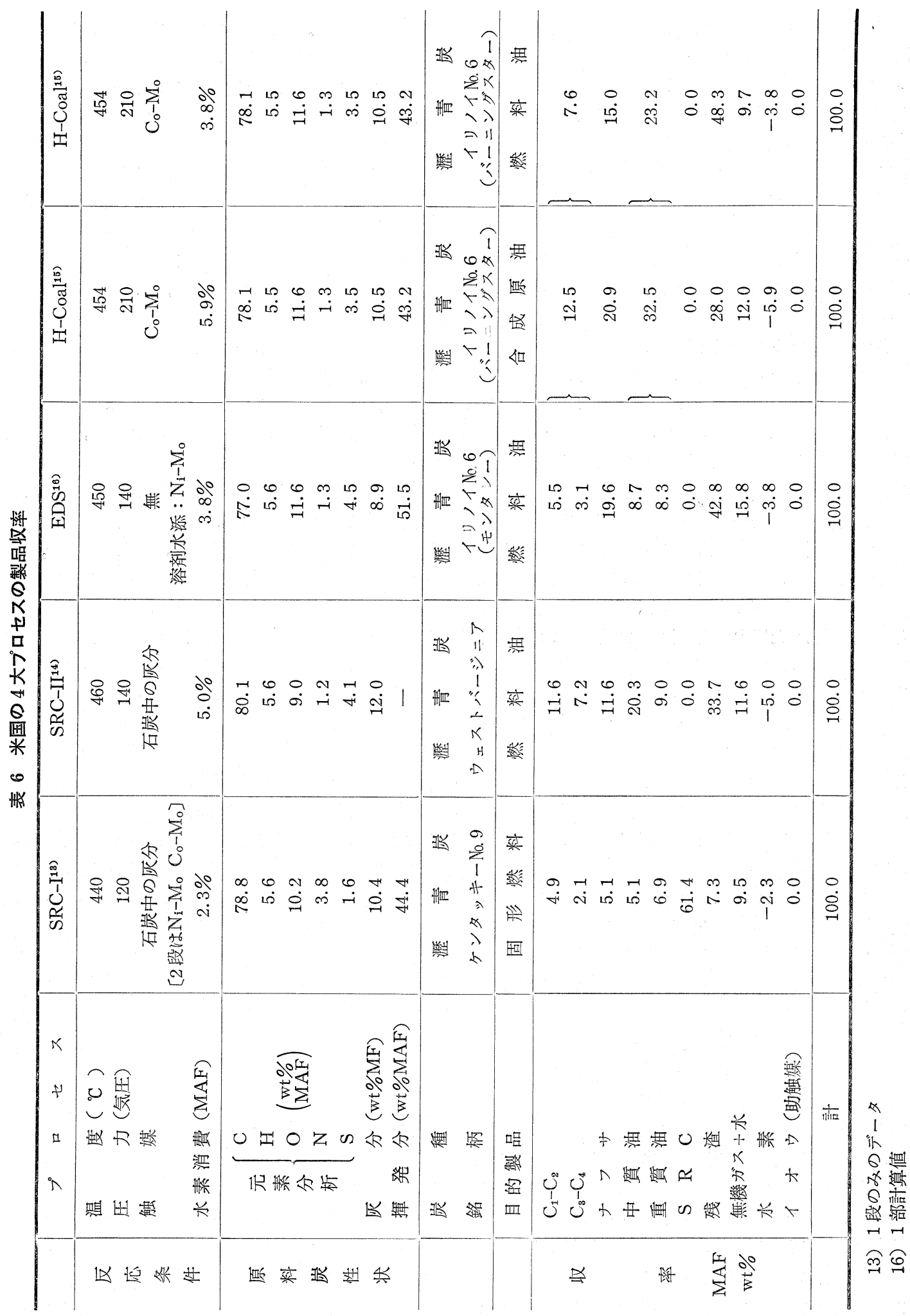


ほどあると言われている ${ }^{12)}$ 。直接法液化技術の中では, 技術的, 経済的にみて SRC-II, EDS, H-Coal の 3 つのプロジェクトが最も注目されている。さらに，主 として固形 SRC (溶剤精製炭) の製造を目的にした SRC-I は 2 段水添を付加して液状油も併産できるよ らにシステムを変更した。SRC-I（TSL-2 段法）も 主要なプロジェクトとして開発が進められている。 SRC-II プロジェクトは，米，西独，日本との政府べ 一スの国際共同開発プロジェクトであるので，参加国 政府の代替エネルギー開発の政策によっても大きく影 響される。

各プロジェクトの概要とプロセスの反応条件と製品 收率の代表的なデータを表 5 ，表 6 亿示す。

1980年 5 月に石炭張込㕛によるパイロットプラント の運転を開発した H-Coal の特徴は 2 つのモードの 運転が可能である，200 T/D の方式では合成原油， $600 \mathrm{~T} / \mathrm{D}$ の方式では, 重質の低硫黄燃料油の収率の 多い生産をする。H-Coal の問題点としては, 触媒 (Co-Mo 系) の活性低下, 触媒口ス, 運転の複雑 さと, 機器の複雑さなどがあげられる。スタート後に レットダウンバルブの故障により，トラブルが生じた

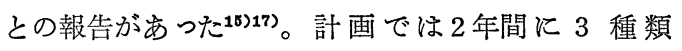
(Kentucky No.11, Illinois No.6, Wyodak) の石 炭のテストを行うことになっている。

1980年 6 月に運転開始したエクソン EDS は，大き なトラブルもなく稼動している。運転時間は1980年 9 月末で, 1,000 時間以上, サービスファクターは約50 \%である ${ }^{18)}$ このプロジェクトは米国内でる R\&Dの 典型的な進め方のひとつとして高く評価されてい

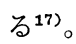

ボトムの処理はフレキシコーカー（70T/D）による 液收率の向上を図る方法と別法として, 部分酸化法も 検討している。プロセスを組み立てる上で，自家使用 燃料と, 水素製造の原料の調達は重要な要因となって いる。

SRC-I と SRC-IIは, Phase-I の設計段階にあ り1983年頃には完了する。一方建設の準備は1981年着 エし，1984年の終りには建設が完了する予定になって いる。デモプラント設計段階に和ける種々の問題点 や，パイロットプラント運転時に和けるエンジニアリ ング上の問題点は 4 つのプロジェクトに共通したもの が多い。どのプロジェクトも米国政府 (DOE) の援助 のもとに進められているためか，このような共通の問 題点の解決には, 頻繁に行われる学会, 団体や研究機 関が主催する Meeting などを通して活発に意見交換
が行われている。エンジニアリング上の問題点につい ては紙面の都合で割愛する。

3.2 プロセスの改良と液化油の性状

石炭液化油などの一般的な性状について Chevron Research Co. (CRC 社) が研究した報告がある。

図 3 亿示寸ように石炭液化油は, 石油, シェールオ イル, サンドオイルと同数の炭素数のものでも $\mathrm{H} / \mathrm{C}$ の最も小さい液体である。つまり液化物は石油に比 へ，芳香族分が多く，側鎖も短く，従って比重が重 い。またへテロ元素については $\mathrm{N}, \mathrm{O}, \mathrm{Cl}$ が多く, $\mathrm{S}$ は石油に比べさ潘ど多くない。また同じ沸点範囲の石 炭液化油之石油製品で, 平均分子量は石炭液化油の方 が小さい。

また，石油系の重質油で問題となる $\mathrm{Ni} ， \mathrm{~V}$ などの メタル分はなく, 石炭中の灰分飞は $\mathrm{SiO}_{2}, \mathrm{Al}_{2} \mathrm{O}_{3}$, $\mathrm{Fe}_{2} \mathrm{O}_{3} \mathrm{CaO}, \mathrm{MgO}, \mathrm{Na}_{2} \mathrm{O}, \mathrm{K}_{2} \mathrm{O}, \mathrm{TiO}_{2}, \mathrm{P}_{2} \mathrm{O}_{5}$, $\mathrm{SO}_{3}, \mathrm{~B}_{2} \mathrm{O}_{3}$ などが液化残渣物の中に含まれて特り, 固液分離工程で除去される。特に炭化度の低い亚㳅青 炭や褐炭には $\mathrm{CaO}$ が多く含まれ, 反応塔の中で, フ ミン酸塩の自動分解により $\mathrm{CaCO}_{3}$ が生成し, 反応塔 内に沈積し，トラブルの原因となる。一方，FeSx は， 触媒効果があり，これを多く含む米東部炭は， SRC-II, および SRC-I プロセスに適する。

石炭液化油の製品目標として「石油製品と同等な品 質」を求めようとすると，図3でもわかるように H/ C 比を大きくさせアロマティクからパラフィニック に富んだ方向を目指さな汀ればならない。すなわち, 安く水素を製造し, 効率よく, 多量传素を消費させ

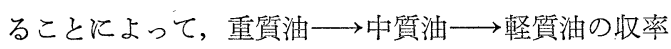
の多い方向へ進みかつ，石油製品の品質に近づく。

石炭液化油の各留分の品質研究については, パイロ ットプラントが稼動し製品が多量に出てきつつあるの で，大規模な実用試験などが可能となった。 SRC-II 燃料油の Consolidated Edison (New York) 飞括斿 る発電用ボイラーに物沙る燃燒性和よび NOx 発生 量実測テストや，定置式ガスタービンの燃焼テストな ぞが行われている ${ }^{14)}$ 。最近の報告の中から特にプロセ スの動向との関連に特いて注目される点を述べる。

従来, 水素化度 4 5\% の場合の重質油分は石 油 系 重油との相容性䝪蔵安定性に 疑問が持たれていた ${ }^{1)} 。$

またボイラー燃料として使用する場合も, 窒素分, 硫黄分が高く, 脱空素, 脱硫の工程が必要となる。乙 か子脱硫反応に比べ脱窒素反応の困難性が明らかにな りつつあり（図 4) 重質油の処置飞苦慮している。ボ トムリサイクルのシステムはもともとガルフ SRC-II 


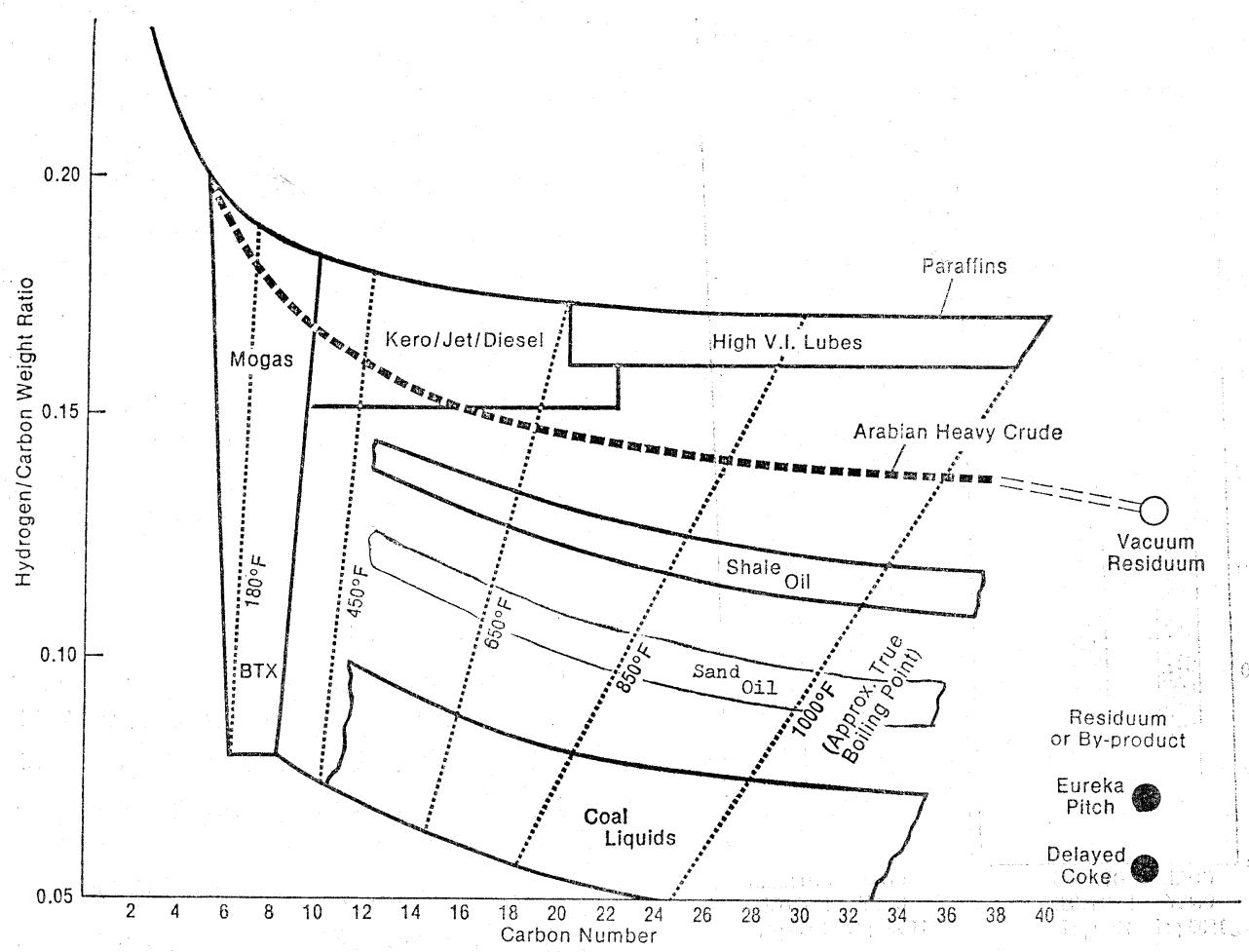

图 3 Hydrogen/Carbon ratios in fuels and raw materials ${ }^{19}$ )

で灰分の濃縮循環のために採用していたるのである が，滅压残渣油をリサイクルすることにより，水素化 度を助長し，製品の安定性を図ると同時に軽質化和よ び製品得率の向上を図ることができる（図 5 )。

ボトムリサイクルのるらひとつの重要な要素として

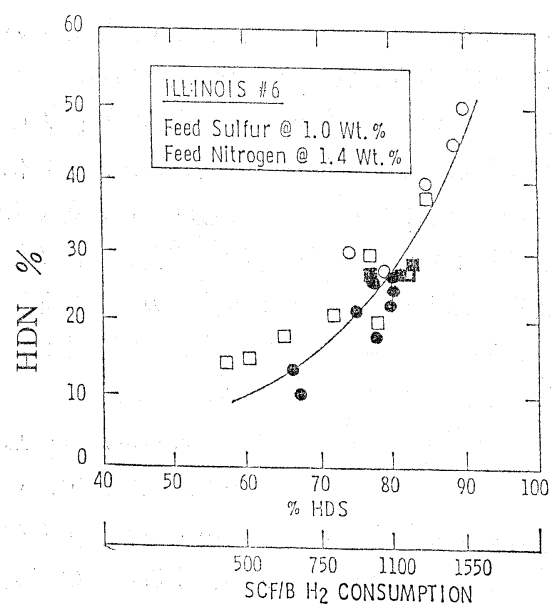

図 4 Upgrading of EDS $750 / 1000^{\circ} \mathrm{F}$ VGO ${ }^{16)}$
減圧残渣油の操作性の問題である。EDS の減圧残椬 油の液化滞留時間と粘度の関係を図 6 亿示す。図 6 上 的炭化度炭程粘度は大きく, 同一の石炭では, 滞留時 間が短い程粘度は大きい21)。ボトムリサイクルするこ とにより減圧残渣油の粘度は緩和され貯蔵安定性も改 善される（図 7)。この理由としては，図8亿示すよ らに減圧残渣油中のプレアスファルテンが減少し; ア スファルテン含量が増加するためと考光られる。運転 操作上，ポンピング可能な限界值として50ポイズとす れば，減圧蒸留塔でのカット温度が定まる。EDS:の

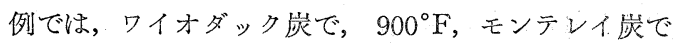
$975^{\circ} \mathrm{F}$ となる。

\section{3 アップグレーディング技術}

アップグレーディング技術は, 石炭液化プロセスを 主とすれば, 從の関係にある。液化留分はナフサ留分 または軽質留分 $\left(\mathrm{C} 5 \sim 380^{\circ} \mathrm{F}\right.$ 一一沸点範囲の定義はな い。これは SRC-II の場合, 以下同様), 中質留分 $\left(380-600^{\circ} \mathrm{F}\right)$, 重質油留分 $\left(600-900^{\circ} \mathrm{F}\right)$ 飞分離で きる。各留分を用途に応じた品質性状の評価を行い, アップグレーディングの方法についてをとめたのが 表 7 である。 


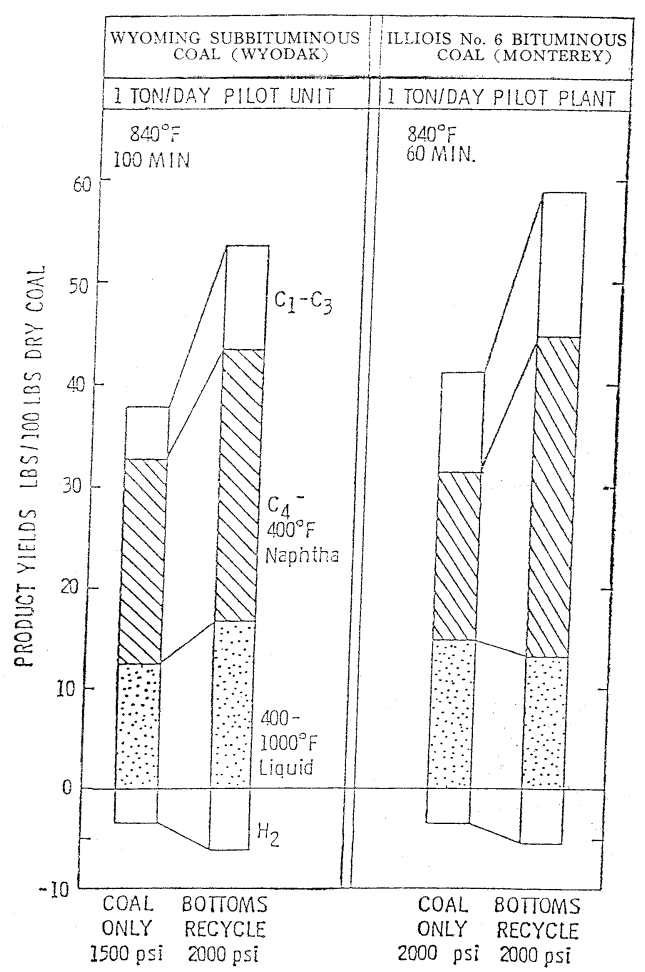

图 5 EDS bottoms recycle improves liquid yield and produces a lighter product slate ${ }^{16)}$

アップグレーディング技術については大きく(1)へテ 口元素を除去し, クリーン化を図る方法, (2)改質, 分 解などの付加価值を高める方法とに分けられる。

(1)は水素化精製により，S，N，O，は除去できる が，前述のように脱窒素反応は脱硫反応に比べ，反応 速度が遅く，芳香族環中の $\mathrm{N}$ 分は容易でない27228。従 ってへテロ元素の含有量により反応の苛酷度が異な る。一般に石油系に比べ高苛酷度が要求される ${ }^{22)}$ 。水 素化精製後のナフサ留分の改質反応は石油系のそれよ りも良好な結果が得られている14)16)26)。すなわち，(a) オクタン価が高い, (b)水素発生量が多い, (c)リフォ一 メート収率が高い，(d)SV が高いなどである。

中質留分のアップグレーディングとして, UOP 社 $\mathrm{CRC}$ 社では，FCC や水素化分解により軽質化し方 ソリン, ジェット燃料, 灯油, ディーゼル然料などの 製造研究を行っている20)28)28)。

CRC 社は，まずアップグレーディングの方法とし て, SRC-II 石炭液化全留分を一度に水素化精製し, 蒸留した各留分のアップグレーディングのモデルをい

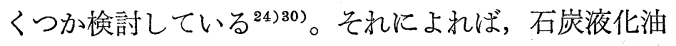

から苛酷な水素化精製反応と FCC を組み合わせて， オクタン価95.3(リサーチ法)のガソリンを生産するコ ストは $17.5 \$ / \mathrm{bbl}(1980$ 年 1 四半期価格) $2 / 3$ をo. 2 Fuel Oil を併産するケースでは，10\$/bblになる。 UOP 社の場合は石炭液化油の各留分毎にアップグ レーディングを考えて研究を行っている。

つまり, 米国のアップグレーディングの技術開発は この 2 社に代表されるように, 既存の石油精製プラン トの設備, 触某, 処理システムなどがどの程度まで活 用できるか，の研究が進められている。

日本の場合には, 資源国の山元で生産される石炭液 化油を, 輸送可能な合成原油の形で太平洋岸の製油所 に受入れ，石油精製プラントでアップグレーディング する方法は将来考光られるであろう。

\section{4. 液化プロセス開発の最近の動问}

（1）液化油の製品の目標はより軽質化に向っている

それは図 9 の逆Y字型のB点からC点への方向で示 される。1) 以前, 筆者らは製品の目標は水素化度の両 端域から中間域に歩み寄る傾向にあることを指摘し た。

その集なる点が(B)点であった。最近B点から C 点に 目標が移行しつつある, すなわち, ボイラー燃料指向 から輸送用然料あるいは中，軽質然料油指向に変わり つつあるように見受けられる。

溶蝺抽出法では, ガルフが固形 SRC（固形ボイラ 一然料)。の SRC-I から液状の重質油指向の SRC-II あるいは SRC-I の 2 段水添へと変った。高級触媒を 使う方式では，管型固定床の Synthoil 法が脱落 し, H-Coal ほ軽質油指向から重質油（フューエルオ イルモード) と中軽質油指向（シンクルードモード） に変った。そしてェクソンが目標として設定していた のもこれらの集まる地点, つまりB点である。

(B)点は SRC の収率曲線が斜線を施した破線との交 叉する点である。この破線は，水素製造用にガス化す る $\mathrm{SRC} の$ 量を示している。 (B)点は，ここまで水素 化した時の反応生成物を常圧，減圧蒸留して，その留 出油の方を製品とし，減圧ボトム油の方をガス化装置 に迴して，ちょらど消費しきる物質収支を意味し，水 素化度ほ憈青炭ならば 4 4.5wt\% である。

エクソン EDS, ガルフ SRC-II ともに，この点を 目標としており，触媒を使わない溶剤抽出法で，これ だけの水素化を達成するために，ボトムリサイクルや 溶剤を水素化して水素供与性を富化するなどの工夫を 施している。そして製品はボイラー然料用途の重質液 状油である。 


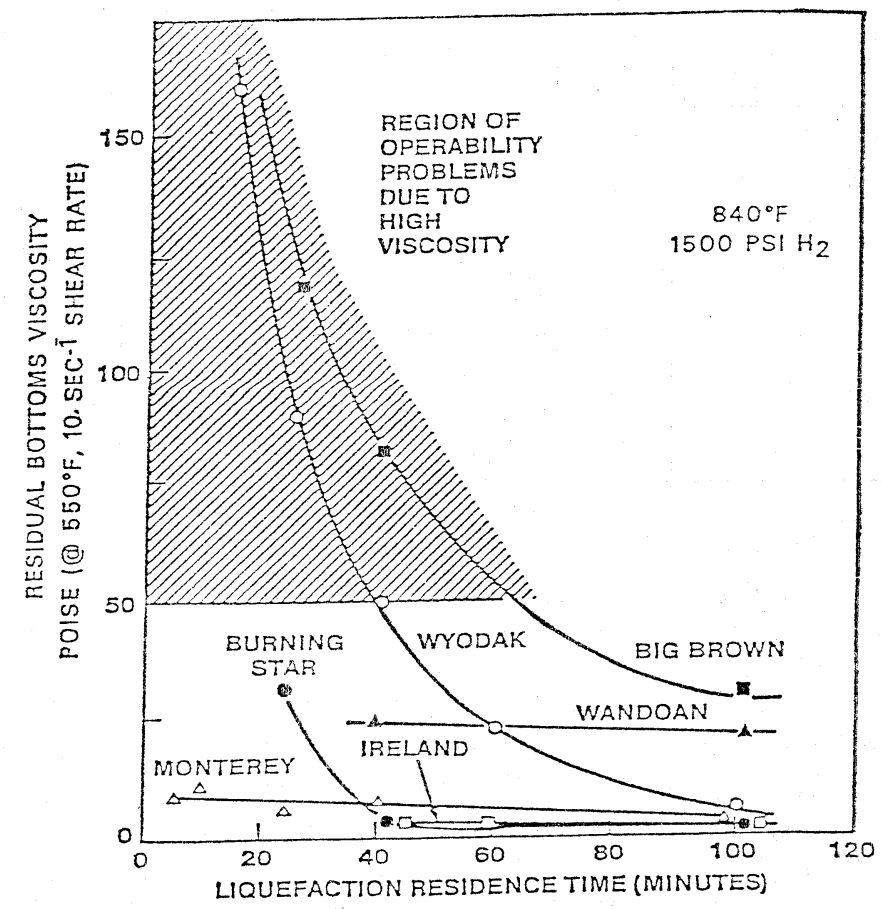

図 6 Residual liquefaction bottoms viscosity is an effective index to operability for different rank coals ${ }^{16)}$

この囚点まで水素化する技術が確立された時，次の 挑戦は適用炭種を亜歴青炭, 褐炭まで拡げることと, より軽質油を製造することであった。EDS の場合で いえば, 褐炭までの拡大は可能で, その最適運転条件 や経済性もほぼ把握されているし，より軽質化するこ とも可能であるとされている。この軽質化を可能にし

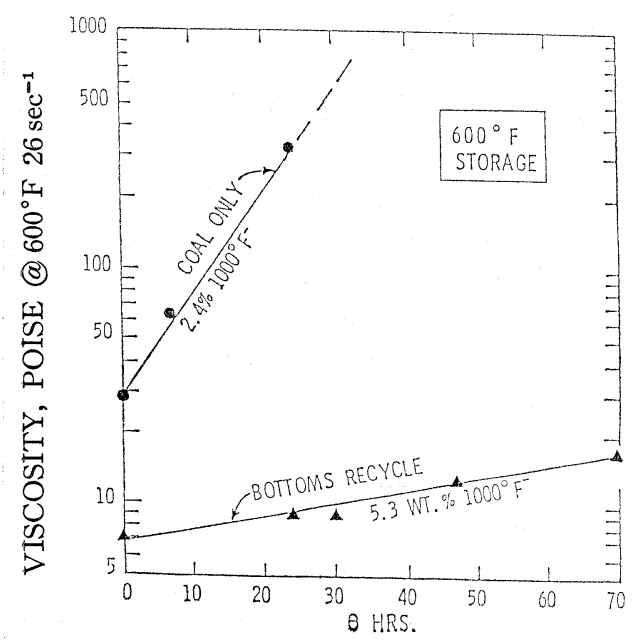

図 7 Storage stability of illinois bottoms ${ }^{16}$ )

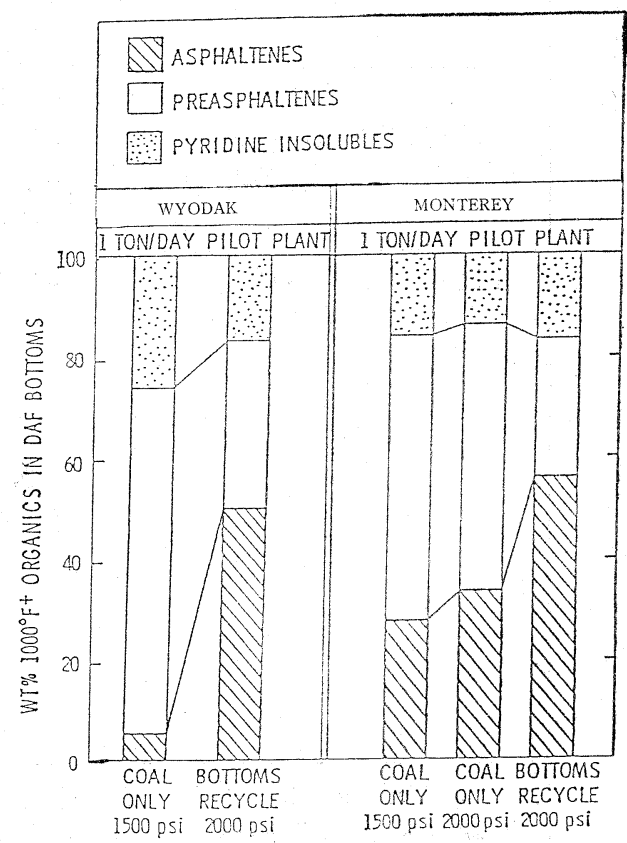

图 8 Bottoms recyele improves solubility of bottoms product from coal ${ }^{16)}$ 
表 7 石炭液化油の性状とアップ

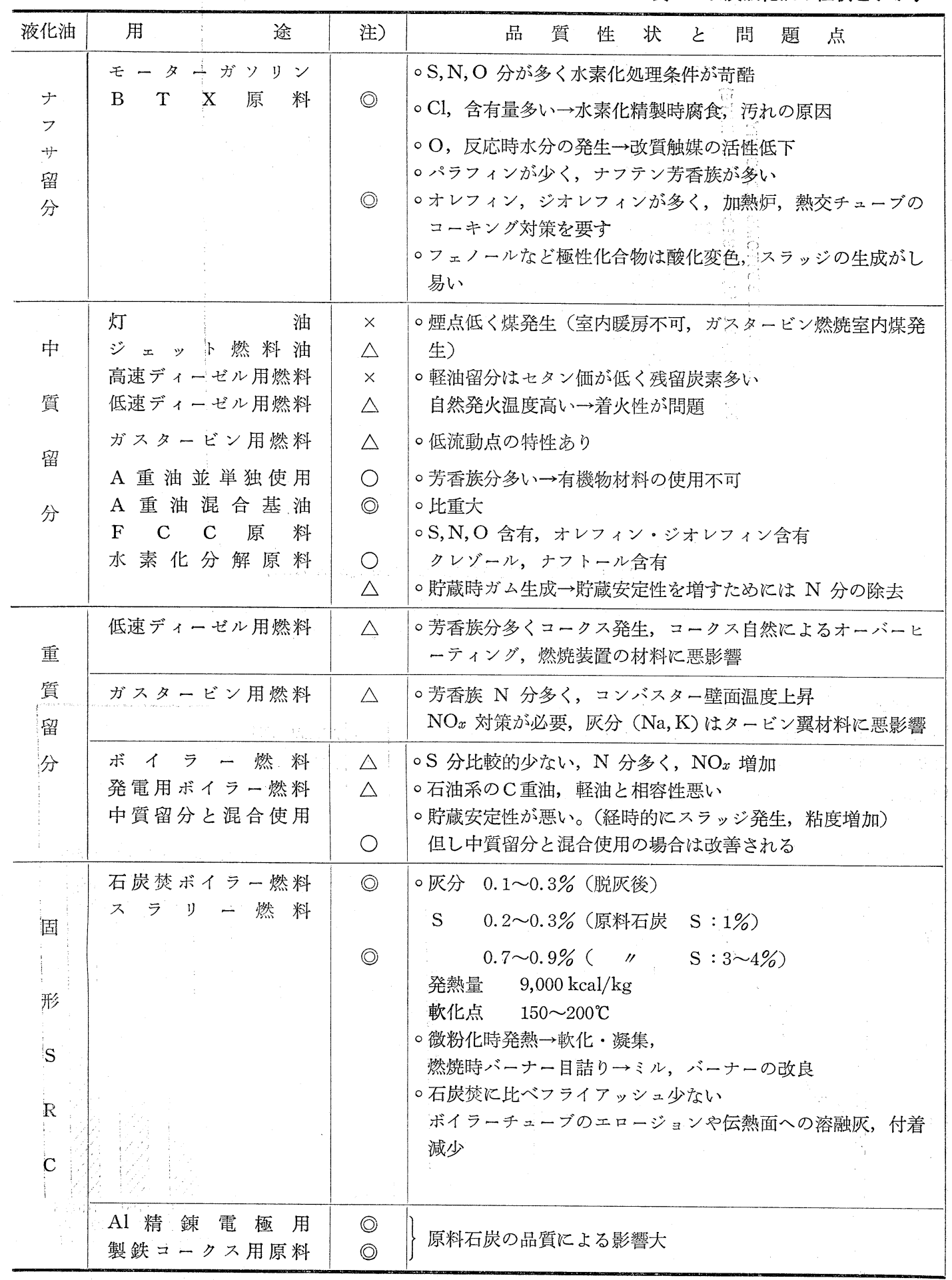

注) (……石油製品に劣らない、○…可能性大のもの $\triangle \cdots \cdots \cdot$ 改良研究，アップグレーティングを必要 
グレーディング1)7)14)20)22)23)24)25)

アップグレーディングの方法

\begin{tabular}{|c|}
\hline \\
\hline 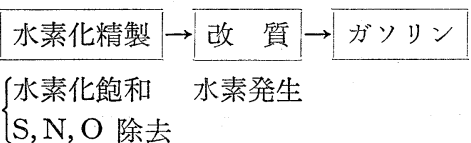 \\
\hline
\end{tabular}

○オクタン価 (リサーチ法) の推移（例）

処理前 80 精製後 60 改質後 105

水素化精製 $\rightarrow$ F C C $\rightarrow$ $\rightarrow$

芳香族分の減少

特飞 $\mathrm{N}$ 分の除去

水素化精製 $\rightarrow$ 水素化分解 $\rightarrow$ 灯軽油等

$\mathrm{S}, \mathrm{N}, \mathrm{O}$ の除去

ジオンフィンの水素化

○ジェット燃料油は高苛酷度の水素化処理により規

格に注沽合格（但し比重は外れる）

\begin{tabular}{|c|c|c|}
\hline 水素化精製 & $\begin{array}{l}\text { ボイラー用 } \\
\text { ガスタービン用 }\end{array}$ & $\rightarrow$ \\
\hline $\begin{array}{l}\text { 脱硫, 脱窒素 } \\
\text { 低粘度化 } \\
\text { 低流動点化 }\end{array}$ & & $\begin{array}{l}\text { 水素化精製 } \\
\text { を行わずす, } \\
\text { 排出基準に } \\
\text { 合格しない } \\
\text { 昜合 }\end{array}$ \\
\hline
\end{tabular}

微粉化 $\rightarrow$ 石炭ボイラー $\rightarrow$ 排煙脱硝（硫）,除塵

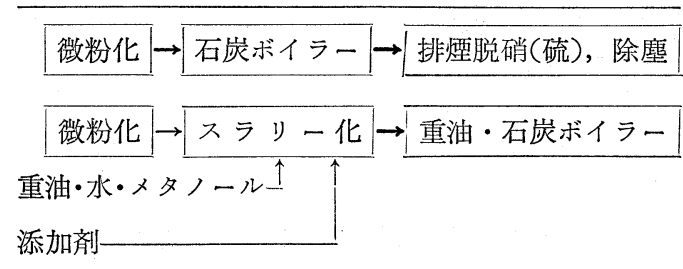

○脱在

○脱硫, 脱窒素

とする ×……あり向かない。
たのは前述したように減圧ボトムのリサイクルの技術 である。このボトムリサイクルの技術は, 灰分の濃縮 循環による扊の触媒作用の活用, 重質油分の滞留時間 延長による軽質化の促進といらメリットがあるため, EDS，SRC-II ではこのボトムリサイクルをより徹 底することの効果が明らかとなり, 重質油から中軽質 油指向 (輸送用燃料用途) への目標の移行の可能性が 出てきたものである。

(2)これよりさら軽質化を進める時は, 次の目標水 素化度は(点であうう。

図10で(A)，(B)，(C)の 3 点は溶剈抽出法の水素化深度 の三つの到達点を示している。

まず(A)点は固形 SRC を得るプロセス型の目標水素 化度で, フィルター法などの機械的固液分離法で脱灰 をするに必要な粘度を得るためのものである。

B点は，反応生成物を常圧，特よび減圧蒸留して留 出品を製品とし, 減圧ボトムは水素製造用原料とし て，ガス化してちょうど消費しきる物質収支のバラン ス点である。(A)点とB点の中間域の水素化度で設計し た場合には, 液状油と固形 SRC の併産型となる。

固形 SRC は硫黄分, 窒素分はさほぼ低隇されてお らず，単に無灰であるといらだけで，かつ固形のわず らわしさもあって，魅力は薄い。

液状油を少しでも多く採りたいとして設計を(B)点に 近づける時には, 固形 SRC の生産量は減少し, その 少ない SRC のために複雑な設備と運転を保持せねば ならず，好なしくない。かといって，蒸留法によらず 機械的固液分離法により脱灰して, 留出油分とボトム 油分を未分離のます製品とするのは, 製品品質を著し く劣化させるので，これる好ましくない。

蒸留により減圧ボトム油を分離し, 留出油分のみを 製品とすることは, 灰分の濃縮分離といらことの他に プレアスファルテン, アスファルテンの濃縮分離を行 らので製品となる留出油分は, 未分離の場合に比較す ると硫黄分, 窒素分が低く, 貯蔵安定性, 混合安定性 も向上するというアップグレーディングの効果的な方 法であり。ここがフィルターなどの機械的分離などが 単に灰分を分離するだけであることと比べて，大きく 異なる点である。

さて次に，B点を離れてさらに軽質化を進めようと すると, 次の上陸地点は(点になるのではないか。

これは灰分のリッチな減圧ボトム油の運転可能な粘 度で決められる。たと爷ば，灰分 $8 \%$ の石炭を装入す るとして, 減圧ボトム油が灰分 $40 \%$ まで濃縮しても運 転可能であるならば，ボトム油中に油分を $12 \%$ 残して 


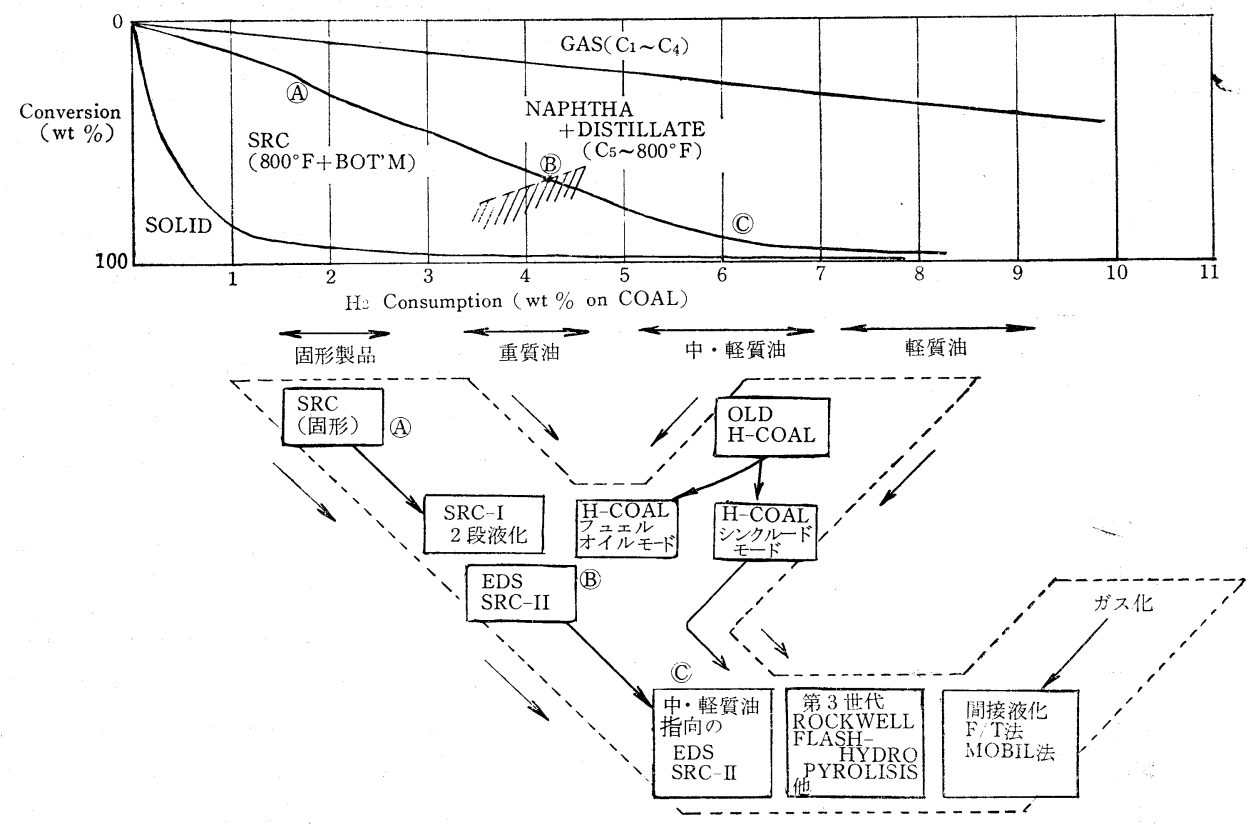

図 9 石炭直接液化技術の開発の動向-(1)

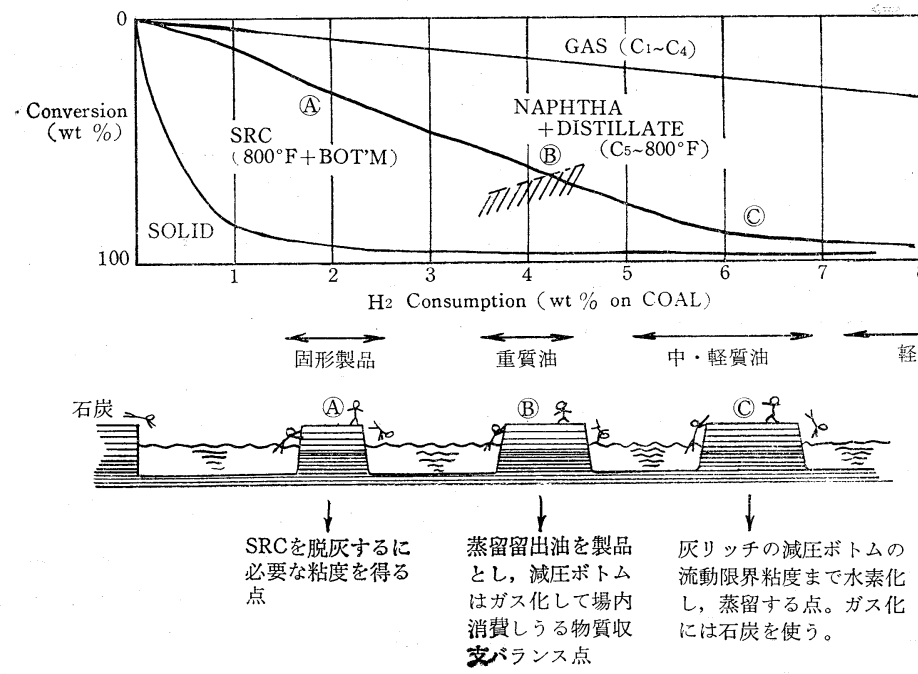

図 10 石炭直接液化技術の開発の動向-(2)

あとは全部留出油として取り出せるような水素化度む で水素化する，これが(C)点である。

この辺では，重質油分中のプレアスファルテンもほ とんどアスファルテンに転化しているので流動性もあ り，それだけ灰分を多く含有することができる。

B， C) 間域では，水素化装置の原料として石炭
を使用せねばならない。もしボトムリサイクルを適用 して㪕質化を図ることに，コスト，品質の点でメリッ トがあるとなれば， C点まで行きついた方が得であろ ら。ボトムリサイクルを採用して水素化度を深めるこ とはコストを高め, 設備や運転面でも複雑になること であるが，同時に製品価值も高まるのであり，全体と 


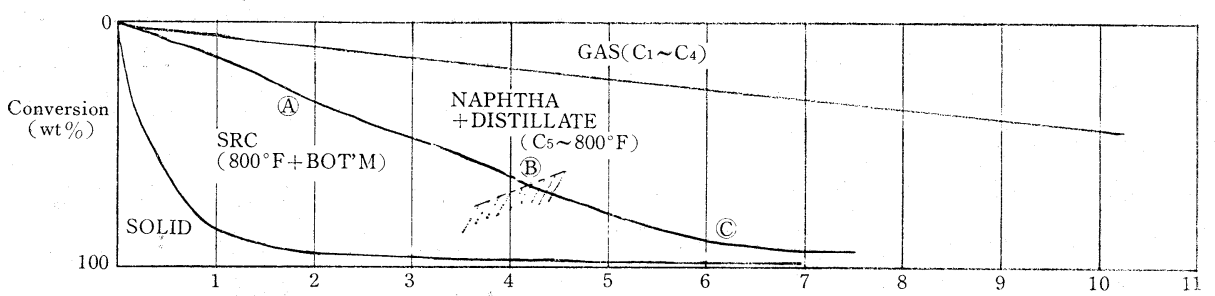

$\mathrm{H} 2$ Consumption (wt $\%$ on COAL)

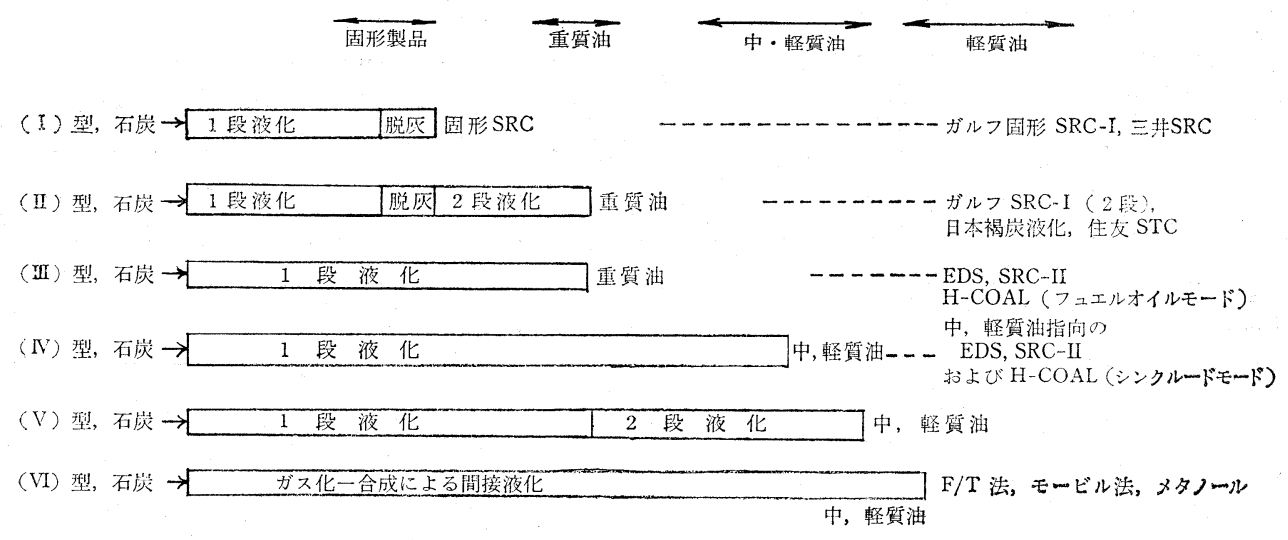

図 11 石炭直接液化技術の開発の動向-(3)

してメリットを生ずるのであればC点まで行きつく方 がよいと判断されるであろら。

（3） C点を再度離れて，より軽質化に向からことは ありらるであろらか。

このC点まで水素化して減圧蒸留法で灰分を分離す るシステムでは逆に, それ以上注水素化を進められ ないという制限を持っている。減圧ボトムからの排出 に必要な粘度を維持するだけの油分を残すためであ る。

溶剤抽出法でこの拘束を脱するには, 図11の(V)型 のように蒸留留出油の 2 段液化の方式をとることにな ろら。または蒸留法によら奴灰分とアスファルテンの よい分離法が確立される必要がある。

(C)点は中軽質油指向でその用途は輸送用ならびそ中 軽質然料油となるが，ここまでくると同じ指向をるつ 別のプロセスが視野に入ってくる。

ひとつは第 3 世代の直接液化技術であり, 二つ目は 間接液化技術である。従来, ボイラー燃料指向の直 接液化之輸送用燃料指向の間接液化の長短を定量的に 比較することは難しかったのであるが，それが最終製 品が類似してくるとより正確に比較でさるようにな る。

\section{5. わおりに}

石炭資源国米国の石炭利用技術開発は急ピッチで進 められようとしている。そして技術開発の状況にせ よ，周囲の社会環境にせよ，年々目まぐるしく変化し つつあり，わが国に扮いても常に大胆に発想を転換し ていかねばならないと痛感する。

\section{文献}

1）志鷹義明, 燃協誌，57，955 (1978)

2）世界エネルギー会議資料（1977）

3) Keystone Coal Industry Manual (1980)

4）コール・ノート昭和 54 年度版 資源エネルギー庁 石炭部監修

5) Coal Age 76, May (1980)

6) W.E. Taylor, R. J. Kalter, Western Coal, Lexington Books (1978)

7）神谷佳男，燃焪誌，59，229（1980）

8) Primary data from Office of Tech. Assessment Direct Use of Coal (1979)

9）電力中央研究所報告：579004 昭和53年 3 月

10) Monthly Energy Review; DOE (1980)

11) Synfuels Nov. 21 (1980)

12）石炭液化の現状について 昭和54年11月 通産省

13) S. M. Morris, (Airpro) et al., 88 th AIChE 
Annual Meeting Feb. (1980)

14) J.Freel (Gulf) et al., Conference on Synthetic Fuels: Status and Directions San Francisco Oct. (1980)

15) R. M.Eccles, (HRI) et al., ibid.,

16）池田定昭，吉武邦樹，“石炭資源開発・液化技術” フジテクノシステム (1981)

17) G. Fumich, Jr. (DOE) Conference on Synthetic Fuels: Status and Directions, Oct. (1980)

18) W.R. Epperly (ERE) et al., ibid.,

19) A. G. Bridge, G.D. Gould (CRC), JPI Symposium Tokyo Oct. (1980)

20) V.A. Gembicki et al., 1980 UOP Process Div. Tech. Conference Apr-Sep (1980)

21) W.N. Mitchell et al., Lignite Symposium Grand Forks, May (1979)
22) A. J. De Rosset et al., (UOP) 44 th Midyear Refining Meeting of API. May (1979)

23) R. E. Corser et al., (UOP) AIChE, 87 th National Meeting, Aug. (1979)

24) H. A. Frumkin et al., (CRC) ibid.,

25）電力中央研究所，調査報告：279005昭和54年 9 月

26) J. R. Armand et al., (UOP) Hydrocarbon Processing, 152 May (1979)

27) B.C.Gates, et al., (Deraware U.) Seventh Quarterly Report ERDA FE-2028-3 (1977)

28) L. Berg et al., (Montana State U.) Interim Report. June-Aug ERDA FE-2034-8 (1977)

29) R.F. Sullivan et al., (CRC) 44 th Refining Midyear Meeting, May (1979)

30) R. F. Sullivan et al., (CRC) AIChE 87 th National Meeting, Aug. (1979)

\title{
Coal Situations, Coal Policies and the Status of Coal Liquefaction Process Development in USA
}

\author{
Masahiro YoshIDA, Yoshiaki SHITAKA
}

(Idemitsu Kosan Co.)

SYNOPSIS : - The trend of coal liquifaction process developments, especially SRC-I, SRC-II, EDS and H-coal, is described. It should be noted that the process is being improved for producing light distillate and middle distillate at $5 \sim 7 \%$ hydrogenation, which can allow ash-rich vacuum residue of coal liquid to be handled as slurry. 